\title{
Originalia
}

Jadranka Milovanovic*

\section{Humility and its role for healing in the work of C.G. Jung and Kurt Schwitters}

\author{
Demut und ihre Bedeutung für Heilung in den Arbeiten von C.G. Jung und Kurt Schwitters
}

https://doi.org/10.1515/spircare-2021-0032

Vorab online veröffentlicht 03.06.2021

\begin{abstract}
Humility of universal value. It pervades different layers of human existence. Examples abide in religion, in psychology, and art. Its presence offers rich sources of material and interesting parallels with Jung's writings. Humility is unfortunately generally viewed as a weakness to the point of ridicule. In this view it is something to be avoided, hidden, rejected, or in some cases concealed by the opposite attitude such as false humility. In Jungian Psychology this weakness belongs to the shadow side of personality and is related to ego defenses. This is why Jung views humility as the acceptance of the shadow and considers it necessary for healing in the process of individuation. The immediate parallel is to be found in the words of St. Paul Cor. 12,9; "my power is manifest in weakness"; referring to the kind of weakness which means being completely supple, transparent, and abandoned to the power that goes beyond our conscious mind.
\end{abstract}

Keywords: Humility, healing, transformation, C. G. Jung, art

Zusammenfassung: Entgegen der heute landläufig eher abwertenden Deutung einer demütigen Haltung als Ausdruck mangelnden Selbstwertgefühls werden in dieser Übersichtsarbeit verschiedene Facetten der Demut als Tugend und Charakterstärke in der Anerkennung eigener Schwäche beleuchtet. Die antike Sicht der Demut als Qualität mit heilsamer Auswirkung auf das Seelenleben kann durch die moderne Psychologie bestätigt werden. Demut hilft, sich mit der inneren Ganzheit zu verbinden und ist im Heilungsprozess immer schon wichtig - sowohl auf der Therapeuten- als auch auf der Patientenseite. Sie setzt

*Korrespondenzautorin: Jadranka Milovanovic MSc, Diploma in Analytic Psychology; Group Memeber IAAP; C.G. Jung-Institut; Hornweg 28, CH-8700 Kusnacht, E-Mail: jadrankamilo@gmail.com beide in die gleiche Position in der Beziehung zum göttlichen Heiler.

Etymologisch leitet sich humilitas, das lateinische Wort für Demut, vom Wort humus, Erde, ab, das wohl auch dem Wort homo, Mensch, zugrunde liegt. Menschsein wird mit Demütig-Sein verknüpft.

Im Altertum und in den verschiedenen Weltreligionen ist die adäquate Haltung gegenüber Gott und Göttern die der Demut. Der Mensch weiß um seinen Platz im Universum, um seine Abhängigkeit in der kosmischen Ordnung. Im Christentum erhöht Gott die Niedrigen, Christus, Gott und Mensch, erniedrigt sich selbst. Im Islam gilt es, sich Allah zu unterwerfen, um aufgehoben zu werden, im Buddhismus führt der Weg zur Erleuchtung über das Hintanstellen des Ich, im Taoismus besiegt das Weiche das Harte; man verbeugt sich.

In der modernen Gesellschaft allerdings wird die Abhängigkeit von höheren Mächten nicht mehr akzeptiert, der Schwerpunkt wird auf die eigene Kraft, auf die Entwicklung des Selbstbewusstseins, auf Stolz und Ich-Bezogenheit gelegt.

In der Psychologie, die nun mit der positiven Psychologie ihre „vierte Welle“ durchläuft, hat man das Phänomen der Demut in neuen Studien wieder entdeckt. Sie wird sowohl als trait - als auch als state - Merkmal aufgefasst. Ein Zusammenhang zwischen hohem inneren Selbstbewusstsein und Gewalt wurde gefunden. Die Überwindung von Stolz und Egoismus hingegen wird von der modernen Psychologie zunehmend wieder als heilsam aufgefasst. So hat eine demütig offene, geduldige und vertrauensvolle Haltung positiven Einfluss auf das Wohlbefinden - sowohl intrapersonell durch gute Selbstregulation, als auch interpersonell und gesamtgesellschaftlich durch Beziehungen, die von Empathie, Sorge, Vergebung und Respekt geprägt sind. Reduktion des Egoismus mildert sogar die Angst vor dem Tod.

Speziell in der Psychotherapie von Jung wird Ganzheit nicht als Perfektion, sondern als Vollständigkeit (unter Integration auch des Schattens) aufgefasst. In der existen- 
ziellen Begegnung zwischen Patient und Therapeut interagieren zwei psychische Systeme mit Bewusstem und Unbewussten in Übertragung und Gegenübertragung. Beide teilen im Heilungsprozess Leiden und die dadurch bedingte Transformation von Einseitigkeit in Ganzheit. Der durch persönliche und kollektive Einflüsse selbst verwundete Therapeut bleibt während der Behandlung mit seinen eigenen Wunden verbunden und erfährt in Demut, dass Heilung sich außerhalb seiner Kontrolle ereignet; der Patient erfährt die Gnade der Heilung erst durch die Erfahrung des Scheiterns und des Leidens, die demütig macht. Dabei kommen beide mit der transpersonalen Dimension des Seins in Berührung.

Es folgen Fallbeispiele aus der Praxis.

Auch in der Kunst, im kreativen Prozess, liegt eine transformative Kraft. Als Beispiel wird unter anderem Kurt Schwitters' Schaffen beschrieben. Für ihn ist Kunst eine spirituelle Funktion des Menschen, eine existenzielle Kommunikation, in der vom Betrachter eine Antwort erwartet wird. Kunst reflektiert die Zeit, in der sie entsteht. In der entbehrungsreichen Nachkriegszeit gestaltete Schwitters demütig aus Weggeworfenem, Zerbrochenem und Zerrissenem Kunst. Aus Schatten und aus „niedrigstem“ Material versuchte er, Werke mit neuer Ganzheit zu schaffen und dabei poetische Schönheit auszugraben.

Schlussfolgernd wird der Bedarf gesehen, wieder eine Haltung der Demut anzunehmen und zu kultivieren. Das kann durch Gebet gelingen, durch Reduktion der Terminvielfalt, durch Selbstfürsorge, Naturnähe, Nähe zu anderen. Demut ist dann eine Lebensweisheit und Lebensweise, ohne die es kein Wohlbefinden und kein Gefühl von Ganzheit geben kann.

Schlüsselwörter: Demut, Heilung, Transformation, C. G. Jung, Kunst

\section{Introduction}

\author{
Do not let me hear \\ Of the wisdom of old men, but rather of their folly, \\ Their fear of fear and frenzy, their fear of possession, \\ of belonging to another, or to others, or to God. \\ The only wisdom we can hope to acquire \\ Is the wisdom of humility; humility is endless. \\ T.S. Eliott
}

My interest and quest for humility comes from a long journey as a healer. Initially, when I was a cardiac surgery nurse, the medical model of healing exerted the most influence on me. Over the years, in psychotherapy practice, I was earnestly looking to expand my healing practices whenever I encountered some kind of limitation in my work, incorporating both body and mind as well as the spiritual aspect. Gradually I started noticing that despite my spirituality, training, and better interventions, I was not able to affect a lasting change in my patients' lives. I even became infected by their hopelessness and begun to feel burnt out. I realized that I too was in need of healing. My previously held views stemming from the medical model, collapsed and paved the way to the new direction: the one of a wounded-healer. Within this context, my practice has been changing towards considering and incorporating the influence from the healing archetype. Today, I lean towards being more open to my patients who come from all walks of life, and who bring with them various strengths including cultural and religious backgrounds. My experience of humility guides me to help them cultivate humility in their lives, in particular, when it comes to keeping realistic views of themselves, being more forgiving and accepting of themselves, and being more open and hopeful in matters that go beyond their conscious understanding.

\section{Etymological meaning of humility}

The word "humility" comes from the Latin word "humilitas", a noun related to the adjective "humilis" which is generally translated as "humble." It can also be translated as "grounded" or "from the earth", since it derives from "humus" for fertile ground. Given this root meaning it is easy to see humility as something to do with low, close to the ground or ground itself. These draw in associations related to the earth: always there, stepped on, open to rain and sunshine, silent and accepting. We discard and pour refuse we do not need in it, and yet it has the ability to transform it into a new life. It is also ready to receive the seeds we sow, and is able to multiply life. It is invisible and belongs to the Great Mother the ruler of all life that comes from it and lives on it. Similarly, the association to the Moon whose surface both receives the light from the Sun, and despite the fact that sometimes it shines brightly, reflects the sunlight that hits it. With these associations, humility is feminine.

Within the social context, this root meaning of humility can be interpreted as low in status or class, lower compared to higher, less as compared to more, slow as compared to quick. Therefore, humility can be easily confused with low self-esteem, timidity, feelings of inferiority, or self-degradation. With this possible confusion of meaning, humility is devalued, opportunities for restoring its proper meaning 
and cultivating it are lost, and the absence of it must be paid for with grave consequences such as alienation, separation, isolation, loneliness and more suffering.

Particularly in fast paced, industrialized and materialistic countries that put emphasis on doing, acquiring, producing and competing, humility with its associated characteristics is devalued, undesirable, avoided, and often replaced by opposite attitudes like insistence on developing self-esteem, and all that it brings with it like pride, prestige, and arrogance. The examples range from mild to severe, from disguised pride in the form of false humility to excessive pride or hubris.

Within the field of psychotherapy this root meaning of humility can also be misunderstood, devalued, and discarded. Examples abide and vary from different psychological schools of thought, and their varying techniques that promise us to live more effectively by quickly reversing symptoms of suffering through structured protocols in only a couple of sessions. Jungian psychotherapy is also not free of various states of ego inflation. Grandiose and unrealistic attitudes and assumptions of all kinds find their way in the psychotherapeutic process as the unconscious background of the person begins to be explored. These dangers do not only come from the patients, they can originate with the psychotherapists too since they are human, their training analysis limited, and the process of psychotherapy is such that one's issues reemerge. While patients bring their demands for quick fixes, or other forms of resistances, the psychotherapists could fall into the trap of being the "experts", or even worse playing God. The story Jung often told of a rabbi in dialogue with a student beautifully explains what is at stake. In the story a student asked the rabbi: "In the olden days there were men who saw the face of God. Why don't they anymore?" The rabbi replied: "Because no one can stoop so low." Here is the invitation to consider what stooping is; its symbolic aspect in psychotherapy, and what is required to accomplish it in reality, as well as the dangers if both the therapist and the patient do not "stoop".

\section{Historical views of humility and its role for healing}

\author{
Without humility there can be no humanity. \\ John Buchan
}

The Egyptians practiced humility in front of their gods, kings and priests to live a good life. One such indication is seen in the beliefs they held in the multidimensional levels of the self; in the gods who revealed themselves in dreams and delivered messages that could guide them in their human lives and into the life of the dead. They practiced dream incubation with temple rituals (fasting, abstinence and prayer), and consulted priests or dream interpreters for dream analysis. The priest-physicians even helped them through magic (rituals, spells, incarnation talismans and amulets), as well as with healing herbs. It appears that they practiced humility through obedience and adherence to the principle of order. According to the latter, everything had its due place in the world: religion, society and even the seasonal changes. This implied that there was no difference between divine and human justice for the ancient Egyptians, and that everything was governed by a divine power which established and maintained order. This stood in opposition to the contrary forces known as "isfet" or chaos.

It was considered a crime if a person was engaged in jealousy, dishonesty, gluttony, laziness, injustice, and ungratefulness, and the punishments varied from beating, branding, decapitation, drowning and burning, to exile and of course exclusion from afterlife. It was Maat who decided whether a person would successfully reach the afterlife, by weighing their soul against her feather of truth, and this was the personification of the cosmic order and representation of stability in the universe.

Unlike the beliefs in ancient Egypt, ancient Greece believed in the ideal which was confidence in one's power, and goodness based on realistic self-knowledge as the foundation to self-sufficiency, freedom and contentment. The adjectives "humble" and "lowly", had rather negative connotations amongst most of the moral writers of this time (Plato, Aristotle, Socrates) even though they despised vanity and pretension. Pausanias in his "Description of Greece", in Book X dedicated to Phocis, tells us that in the courtyard of the Temple of Apollo at Delphi there were registered useful phrases which read: "know yourself" and "nothing in excess". According to Pliny these letters were even inscribed in gold! The phrase "know yourself" has a high ethical value, and is forceful because it emphasizes humans as thinking beings, curious, and able to face the facts that they need to know, able to understand and to accept themselves. This poignantly translates to selfknowledge, an invitation for introspection, but also into recognition of one's limits. It also implies protection from excessive self-confidence that can lead to a self-destructive independence of the larger cosmic order, as manifested in King Croesus of Lyidia and King Oedipus of Thebes, who were both defeated on the account of their exaggerated self-confidence. In addition to knowledge and the fear of hubris, the Greeks believed that sickness is misfortune 
due to natural/divine causes, and therefore practiced divination, incubation of dreams, and built many temples for healing purposes. They searched to understand the will of their gods so that they can give meaning to various events in their lives and heal themselves.

In contrast, the Old Testament highly valued humility since it stood for one's relationship to the God of the Covenant, an agreement between God and His people, a code of ethics as followed by Noah, Abraham and Moses. In Deuteronomy 8,2-3; we read how God led His people for forty years in the wilderness, "to humble" them and to test them. He wanted to know what, was in their heart, and whether they were able to keep His commandments. He allowed them to be hungry, then fed them with manna so that they will know that they needed every word that proceeds from the mouth of the Lord.

The humble person, "ani" or "anav" originally referred to someone who was materially poor, socially insignificant and vulnerable. It denotes more the condition of a person; the suffering and the afflicted, and as a result one finds her/himself in a lowly condition, which could be physical, material or social. There is also a related verb, "anah" (to humble) that refers to what one might do to one's enemies, but also to what one does to oneself as a spiritual practice. Thus the "ani" is placed on the same level with the person "of a contrite spirit". Zechariah 9,9; speaks of the coming Messianic King as an "ani": "See your king comes to you, righteous and victorious, lowly and riding on a colt, the foal of a donkey." Most translations emphasize the "humble" character of the Messiah, but other instances speak of the Messiah as the "woundedhealer", that is by using a related verb. It is therefore hard to separate the humble circumstances of the Messiah from His Humble character. This follows that " $a$ nav" denotes a condition of character, referring more specifically to those who have learned to be spiritually humble in character and dependent on God because of their afflictions (Isaiah 34,2 and Psalm 37,11). The difference therefore between the two is that the "ani" refers to the needy who depends on God to meet her/his needs; the "anav" refers to the humble one because s/he has chosen to depend on God. So, the first is circumstantial, the second case is a mark of character.

The God of Old Testament is a God of justice. He will judge those who oppress the "ani", and the "ani" will be vindicated by God. The role of God is to reward the faithful ones with prosperity, to defend them from oppression, to spare them from plagues, and other afflictions, and heal them from all diseases. Psalm 113, 4-9; says that "the Father stoops down to help the poor and needy". The idea of wholeness, completeness, and peace is captured in the
Hebrew word "shalom". Healing therefore, is the experience or the process which restores fallen and alienated human beings to communion, friendship and fellowship with God.

In the New Testament we encounter the Biblical core of humility: Jesus's teaching and healing. The Incarnate Son exhibits humility from the manger to the cross, and is expressed in Matthew 11,29; "Take my yoke upon you and learn from Me, because I am meek and humble in heart and you will find rest for your souls." Christ's humility is emphasized before humankind, He who came to serve. Submission before God, humility and meekness are inseparable.

Humility is also a prerequisite to enter God's Kingdom or "whoever wants to become great among you must be your servant, and whoever wants to be first must be slave of all.” (Mark 10, 43-44). In the Synoptic Gospels, Jesus shows his humility in what He does; He brings the good news to the poor, looks on the humble with favor.

In the Gospel according to John, we read the account of the Last Supper, when Jesus's humility was manifested in the washing of the feet of His disciples (John 13,1-17). There are several layers of the meaning of humility in this account. First Jesus displays His humility and His servanthood. For the disciples, the washing of their feet was in direct contrast to their heart attitudes. Walking in sandals on the filthy roads of Israel in the first century made it imperative that feet be washed before a communal meal, especially since people reclined at a low table and feet were very much in evidence. Therefore, when Jesus rose from the table and began to wash their feet, he was doing the work of the lowliest of servants. This stunned his disciples that their Lord and master performed this act of humility and condescension. It was their work to wash His feet! The humility expressed by His act with towel and basin foreshadowed His ultimate act of humility and love on the cross.

Therefore, Jesus's humility in action was in direct contrast with that of His disciples. His disciples, in their human limitations, had failed various times to imitate Him. For example, when it came to the ritual of washing feet, the disciples had argued among themselves as to who was the greatest (Luke 22,24).

Jesus showed his humility also by not boasting of His healing powers. He did not forget that He has been sent and taught by God the Father. He never took credit for the healing He bestowed, but attributed it to the person's individual faith. His purpose was to destroy the works of the enemy: sin, sickness and bondage. He conducted Himself with compassion. In addition, He expressed other emotions like grief, anger, weeping. He dealt with the whole 
man. In numerous accounts Jesus first announced forgiveness of sins, provided instruction for its avoidance, before healing.

The climax of all this is of course when His humility was expressed dying on the cross. He never insisted on His rights and privileges to be honored, but emptied Himself of His reputation. He was content to be seen as ordinary, and did not seek esteem. In Philippians 2,5-8 we read that

Christ Jesus, who being in the form of God, did not consider it robbery to be equal with God, but made Himself of no reputation, taking the form of a bondservant, and coming in the likeness of men. And being found in appearance as a man, He humbled Himself, and became obedient to the point of death, even death of the cross.

In this light the importance of Early Christian writers is seen through their closeness to the source - the writings and teachings by the apostles themselves. These fathers studied the scriptures, singling out many times the importance of humility as the highest virtue of all. One such account comes from St. Augustine who before his conversion, believed that the ideal life was marked by power, success, knowledge, control, leisure and external morality. After his conversion, he believed that the ideal life was marked by humility. He became an eloquent and robust proponent of humility's value. Unlike the thinkers of the classical and modern philosophical traditions, Augustine asserts that humility is not only a significant virtue, but it is the indispensable foundation of human greatness. Augustine repeatedly accused humanity of being full of pride, and in need of receiving salvation through Christ's humility. He often referred to pride as a physical infirmity or "swelling" that could only be healed through Christ's "remedy", "cure" or "medicine" of humility. The climax of his teachings is revealed in his spiritual autobiography "The Confessions" where he reflected on his moments of greatest pain and sorrow, when he relied on himself, while his moments of greatest joy were when he experienced God's humbling grace in his life. This he expressed emphatically in his Confessions:

If you should ask me what are the ways of God, I would tell you that the first is humility, the second is humility, and the third is humility. Do you wish to rise? Begin by descending, lay first the foundation of humility.

This wisdom reflects James 4,6-7; "God resists the proud, but gives grace to the humble."

\section{Humility and its role in Jungian Psychotherapy}

\author{
Wholeness is not so much perfection as completeness. \\ Assimilation of the shadow gives man a body, so to speak; \\ the animal sphere of instinct, as well as the primitive or archaic \\ psyche, emerge and can no longer be repressed by fictions \\ or illusions. In this way man becomes for himself the difficult \\ problem he really is. \\ Jung, CW 16: par.452
}

Jungian psychotherapy addresses the "whole psychic human being": "the psyche reflects, and knows, the whole of existence, and everything works in and through the psyche" (CW 16: par.203); both conscious and unconscious. It is a long-term dialectical relationship between the therapist and the patient, and is directed towards investigating contents and processes of the patient's unconscious with the aim of alleviating a psychic condition that interferes with patient's conscious living. Healing takes place in the relationship based on mutuality, where two psychic systems interact and affect one another. The therapist participates as much as the patient, and is affected by the process. The therapist brings prior experience of working with the unconscious, and her/his personal development. The patient on the other hand, does not only bring her/his vulnerability, but also the potential to heal.

Jung views problems in life (including illness) as opportunities for reflection on how to make more appropriate ego-adaptation; for discovering new attitudes, and making corresponding adjustments. These adaptations are continuous since life can never be solved but outgrown. The Self, as our psychic totality, could be prompting the person towards discovering her/his unique and authentic self.

In comparison with the medical model of healing, psychotherapy embraces the influence of the healing archetype. This means that the psychotherapist is mindful of the existing and inherent basic schema (not just personal but universal) that influences one to perceive and act according to it when one finds him/herself in archetypal situation such as healer-patient.

Unlike the doctor who has all the knowledge, evidencebased methods, and experience to diagnose and treat the sick/infected patient, ambiguity is associated with the therapist. From the very beginning, the therapist is called to accept that she or he does not have all the answers for how to diagnose and treat the patient and needs to create space where something can happen. The latter refers to the therapist letting go of her/his need to know the next step of treatment or of the final outcome. Healing is seen more broadly: from symptom relief to systematic explora- 
tion of the unconscious images Healing will not appear in any perceptible form. It is rather imperceptible, felt as inner growth and best discerned by the person involved. Its timing is more a matter of Kairos than Chronos.

\section{Humility for the therapist}

The choice of helping profession imposes on the therapist to embrace responsibility for working on her/his unconscious. This starts with training analysis, and then opens possibilities for future work on oneself, and is connected to one's own recognition of the need for it. Jung urges therapists to continuously probe into their own depths if they aspire to do so with their patients. He also warns about the vastness and the mystery of the unconscious, and the need for staying alert to the stirrings in oneself since one's complexes are never fully under one's conscious control. He captures this in the following quote:

\footnotetext{
No analysis is capable of banishing all unconsciousness forever. The analyst must go on learning endlessly, and never forget that each new case brings new problems to light and thus gives rise to unconscious assumptions that have never before been constellated (CW 16: par. 239).
}

The therapist is also a wounded-healer. While there is a strong possibility that the psychotherapist could be impaired, and because of that unable to practice, the woundedness of the therapist is part of her/his wholeness and potential for healing others.

The myth of Chiron the Centaur illustrates what lies at the heart of it for the therapist. In its brief account:

\begin{abstract}
Abandoned by his father Saturn, and rejected by his mother Phylira, who preferred to be transformed into a tree rather than raise a creature who was half human and half animal, Chiron was emotionally wounded from the outset. As he matured, he became skilled in the healing arts and mentored by Asclepius, the founder of medicine, as well as Hercules, who subsequently injured Chiron accidentally with an arrow. Chiron's suffering was so extreme that he asked to trade places with a mortal, Prometheus, so that Chiron might die and Prometheus be granted eternal life (Hayes 2002: 97).
\end{abstract}

Chiron's woundedness is seen as consisting of his initial wounding by not knowing his father and by his mother's rejection of his animal part. His re-injury (leg) by Hercules left him with the incurable wound, yet this did not stop him from getting initiated into the healing art and did not interfere with his capacity to heal. His own suffering led him to sacrifice his immortality in exchange for release from it. In its application to the therapist, Chiron's story, speaks of the therapist's personal wounds as holding the potential to heal others on the condition that the therapist remains connected to them and does not project them on the patient out of fear of being perceived as weak or incapable; or, in a worse scenario, out of succumbing to various pressures coming from the patient. The therapist's surrender of omnipotence (professional persona) means the acceptance of the suffering that comes from the relationship with the patient who is going to affect her/him in the most personal way, and lead to fresh confrontations with the unconscious.

The therapist who does not surrender could become wounding. Guggenbuhl-Craig (1971), in his book "Power in Helping Professions", urges therapists in all stages of psychotherapy process to be aware of the danger associated with power, claiming:

[...] the difficulty arises from the analyst out of his own desire to help. He wants to serve his patients, to aid them in their neurotic suffering, to try to stimulate greater consciousness in them. To the best of his knowledge and ability he wants to help his patients selflessly, without which the opposite pole in the unconscious conjures up the charlatan; the analyst who works not for his patients but for himself (Guggenbuhl-Craig 1971: 31).

Some of the indications that the therapist has become wounding are: lack of patience, not engaging the patient and/or paying attention to her/his feedback, getting carried away by some great ideas for helping, focusing more on the outcome vs. the process. Particularly problematic is when the therapist lacks engagement in life outside of her/his profession and in return loses vitality and creativity.

\section{Humility for the patient}

Jung writes: "recognition of the shadow is reason enough for humility, for genuine fear of the abysmal depths in man" (CW 14: par. 452). The patient, like the therapist, has to battle with the shadow. This consists of letting go of the need for control and taking the risk to open up and expose her/his weakness.

Jung writes that: "all powerful all tyrannizing psychic necessity" brings one to the consulting room (CW 17: par. 304). As much as seeking help is a humbling experience, it is only the beginning of what it takes for suffering to be transformed. The patient who is suffering and asking for help could be resisting help without even being aware of doing so.

Jung instructs about the complexities involved in ego surrender by writing: 
something in us wishes to remain a child to be unconscious or, at most, conscious only of the ego; to reject everything strange, or else subject it to our will; to do nothing, or else indulge our own craving for pleasure or power. In all this there is something of the inertia of matter; it is a persistence in the previous state whose range of consciousness is smaller, narrower, and more egoistic than that of the dualistic phase ... the essential feature of the dualistic phase is the widening of the horizon of life, and it is this that is so vigorously resisted (CW 8: par.764-765).

Here Jung draws attention to the unwillingness to let go of the need to be a child as well as inability to transcend suffering that comes from ego's identification with the parental and other complexes that leave the person stuck in a sterile place, and unable to view self, others, and the world in a realistic way. Jung characterizes these ego resistances as coming from the personal unconscious (shadow), and considers them most accessible, and the easiest to experience.

Jung also reminds us that the patient may be challenged by a more robust type of resistance, influenced by the energies coming from the deeper layers (collective) of the psyche. This resistance is enriched by archetypal phantasy and includes themes such as: magician, mana personality, trickster, etc.

This more robust type of resistance is encountered in patients with history of early childhood trauma. Psychological development in these patients has been interfered with by trauma which caused them "unbearable psychic pain or anxiety" ranging from shattering experiences of child abuse to the more "cumulative traumas" of unmet dependency needs. Kalsched (1996) explains what is at stake in his reference to "a second line of defenses". These are the unconscious defenses that split the archetype of one's psychic wholeness into the "attacker" and "protector", the good and the bad, demon and angel, judge and soother. These defenses oppose integration of the conflicting poles from getting integrated into the totality (the Self or "soul") that would have taken place if trauma did not occur. In his more researched work, Kalsched (2015: 88) writes about these defenses under the umbrella term of "Dis" or dissociation. He invites us to consider how these defenses keep a person locked in repetitive, addictive, neurotic suffering, and prevent her/him from engaging "another kind of suffering, a more productive kind of suffering that might lead out of the ingrown, closed circle of Hell". He also writes that it takes a lot of patience and humility for both the patient and the therapist to transform this kind of suffering into "directed, meaningful and authentic suffering” (Kalsched 2015: 90).

In support of the impact of trauma on one's psyche Edinger (1985) writes how these experiences become coagulated. This means that the painful and negative experiences have become fixed around one's ego, and lead to ego's rigidity. This is manifested in the impenetrable persona that keeps the contact with real person impossible. The various defenses have been put in place to guard the patient from re-experiencing her/his wounding experiences, and prevent her/him in correcting unmet dependency needs. In therapy this is seen in the patient's inability to trust the therapist to guide the process. The ego that is not able to regress for this purpose imposes the meaning on the person rather than makes the meaning, and interferes with the person's ability to effectively self-assert or to individuate. Dissolution of these contents requires a lot of humility on both sides, since rushed interference would only call forth power dynamics, and could seriously diminish possibilities for dissolving them.

\section{Humility in the therapeutic field}

The formation of transference/countertransference signifies that the therapeutic relationship between the patient and the therapist has progressed from conscious level of interaction, where they were more different and distant entities, to a deeper unconscious level, one of more familiarity. This means that both of them have surrendered something of themselves. Jung calls this bond a "combination" and explains it as the "mixtum compositum". Jung writes that this bond consists of the "doctor's mental health and the patient's maladjustment" and leads the therapist to the situation where s/he "takes over the sufferings of his patient and shares them with him", and puts her/himself at risk, one "[...] must run it in the nature of things" (CW 16: par. 358). The risk the therapist takes consists of accepting to get affected in the most personal way, and to "the resultant paradoxical blend of positive and negative, of trust and fear, of hope and doubt, of attraction and repulsion [...] characteristic of the initial relationship [...] the primal chaos" (CW 16: par. 375). This causes psychic disorientation to both, known as the "masa confusa"; the unconscious state. In that state, the therapist gets to re-experience her/his own wounds and is forced to go deeper into her/himself as well as stand vulnerable in front of the patient. In that state the therapist is also asked to contain both her/his own struggle as well as that of the patient, and to trust in the unconscious to reveal itself. Jung writes that the activated unconscious appears as the "flurry of unleased opposites and calls forth the attempt to reconcile them, so, that in the words of the alchemists, the great panacea, the medicina catholica, may be born" (CW 16: par. 375). 
In that state the patient stands vulnerable in front of the therapist by unleashing projections. The patient is challenged to make conscious connections with them, and to find the way of taking them back. The conscious realization is the first step towards taking the projections back. This gradually leads to more accurate perception of the therapist as well as oneself. Here the importance lies in the fact that prior to this phase, one's efforts have been on the ego as the driving force at the exclusion of the unconscious. The spirit-instinct split (one of the many) calls for healing and requires one's willingness, as well as capability, to surrender to this process in order to find ways to transcend it.

The ego gains strength by integrating projections and paves the way for the inner healer (the Self) to emerge, not as a third personality but as combining both, and is revealed in symbols that are not products of conscious intentions, but are the result of transformed (canalized) energy released by the struggle of opposites.

The presence of unconscious images is a source of humility for both the patient and the therapist since neither of them willed them into existence. The psyche communicates its own capacity for transcending the struggle of opposites. Even when the therapeutic relationship is strained, patient's psyche is capable of sending an image capable of bridging the most hopeless struggle of constellated opposites, and could move the psychotherapy/individuation process. This puts the patient and the therapist in equal position in relationship to the divine healer. With this realization, the transference/CT shifts. The patient is able to withdraw the projection s/he made on the therapist as the one who can heal her/him and get in touch with her/his inner potential for healing; the therapist's view of the patient also shifts to seeing the patient as capable of healing and capable of transforming something in the therapist too. The therapeutic relationship is also place to witness circumambulation of psychic images and helps both parties experience not only their individual uniqueness, but also their similarities, and give them the opportunity to feel connected as equals.

With the help of ten alchemical plates from Rosarium Philosophorum, Jung accounts the transference phenomena. In summary, the initial unconscious (masa confusa) undergoes transformation in the alchemical vessel (vas hermeticum) with the help of the Mercurius (spirit with paradoxical nature). Mercurius is both the transforming and the transformed element. It is transformed from its lower, uncivilized and chthonic state into the higher, civilized, and light (conscious state), through a serious of operations that form a four-stage process. The transformation is accomplished through combining of masculine and feminine energies into a union that when consummated leads to death. Death then gives birth to the new/third being (filius philosphorum) that combines both natures, and is experienced as the spirit that animates the body (unites instinct with the spirit). This new relationship between the ego and the Self is effectively captured by Jung:

\begin{abstract}
Conscious and unconscious do not make a whole when one of them is suppressed and injured by the other. If they must contend, let it at least be a fair fight with equal rights on both sides. Both are aspects of life. Consciousness should defend its reason and protect itself, and the chaotic life of the unconscious should be given the chance of having its way too-as much of it as we can stand. This means open conflict and open collaboration at once. That evidently is the old game of hammer and anvil: between them the patient iron is forged into an in-destructible whole, an 'individual' (CW 9i: par 522).
\end{abstract}

This is the essence of the healing experience.

In further elaboration of the workings of the healing archetype Guggenbuhl-Craig (1971) writes: when a person becomes ill and seeks an external healer or doctor, the intra-psychic or "inner healer" or "healing factor" is also energized. The wounds or illnesses cannot be healed, even if the external healer is competent, without the action of the "inner healer". The patient in her/his illness looks for the outer healer and projects onto the constellated persona (training, skills, license, reputation) of the doctor her/his "inner physician or healer", and in return disowns this part of her/himself. In that process, the psychotherapist's wounded side, with all its unresolved issues, is activated by the contact with the patient. This opposite side of the archetypal image in the healer is the patient. If the healer does not recognize and contain this side of her/himself and projects it on the patient, it could have harmful and wounding effect on the therapeutic environment, and on the patient. On the other hand, if the psychotherapist is to contain his woundedness and not project it, the patient is given the chance to get in touch and get help from her/ his "inner healer". The end result being the restoration of balance within the polarity of the archetypal image of the patient-healer archetype.

This balance, as Guggenbuhl-Craig (1971) explains, becomes the acknowledgement that the patient is not only the patient but has "inner healer" within; and that there is a patient inside the psychotherapist. This translates into a situation where both parties correct their incomplete views of each other, accept their personal limitations, and acknowledge their bond as the healing one. Feelings of respect, gratitude, mutual admiration, and solidarity develop between them, and are experienced as healing. 


\section{Humility in Art}

\author{
"Art is a spiritual function of man, which aims at freeing him \\ from life's chaos.” \\ Kurt Schwitters
}

Humility has also affected the creative process of the artist, offering parallelism to the transformational forces discussed earlier in Jungian psychology. There is a unique moment in the art and life of German artist Kurt Schwitters (18871948) which corresponds with the advent of World War I, that challenged this artist to re-examine and re-evaluate himself and his purpose as artist. Schwitters strongly believed that art is not simply about making pretty pictures, but that art is essentially communication: it invites response from the onlooker and reflects the time in which it has been produced. Schwitters found himself in a Europe thorn by war; material such as canvas and paints were hard to come by when it was almost impossible to even find bread to eat. He wanted to remain faithful to his vocation as an artist and even in time of hardship continued to exercise his creative powers that came from within and challenged him to work. This, instead of giving in to despair, helped him to find humility within himself when he started to make art out of trash. Earlier in this study I made reference to the earth and in a similar way, Schwitters started to look for and pick broken pieces of furniture and other things he could find to use for making an art that reflects those desperate times. He assembled collages literally out of trash he found in the streets of Hannover. In this situation he realized that he could unearth poetic beauty if only he humbled himself to use these discarded objects and work with them, believing in the transformative power of the creative process. Quoted in Russell (1981) but in Schwitters's own words:

I could see no reason why used tram tickets, bits of driftwood, buttons and old junk from attics and rubbish heaps should not serve well as materials for paintings; they suited the purpose just as well as factory-made paint. It is possible to cry out using bits of old rubbish, and that's what I did, gluing and nailing them together.

In psychotherapy this is seen in working through the shadow contents, by sorting through projections and assembling the discarded and otherwise useless contents into a new whole that transcends the nature of these contents and the author her/himself. Or, as Jung writes:

We might also mention the intimate connection between excrement and gold: the lowest value allies itself to the highest. The alchemists sought the arcane substance from which it was hoped that the mystic figure of the filius philosphorum would emerge ("in stercore invenitur") (CW 5, par: 276).
Schwitters produced a new aesthetic of scarcity, made with anything which came to hand. It was humility that showed him the necessary internal change he had to experience in realizing that in the debris of the broken warthorn industrial world, he had to try and reconcile a new world order through his humble artistic act. In the end, Schwitters championed a complete re-evaluation of the value of materials, as the new tools of the age, the very act of creation and the importance of his change of heart as an artist. The banal objects that he used, defied the boundaries that exist between high conceptions we generally have of fine art and everyday objects. Schwitters therefore has demonstrated that there is a poet within us all, that has the potential to show us the unobserved elements of beauty that are spread all around us, and that we can find them everywhere, in the gloomy as well as in the insignificant, if only we care to look, to choose, and to fit them into a comely order.

\section{Conclusion}

The need for humility has always been there and modernday healers are called to embrace it in their lives and practice, and find the ways for cultivating it. Contrary to tremendous skepticism and misuse of it, humility is a multifaceted quality with various healing benefits. It is indispensable for the healing process! The true meaning of humility is always connected to one's journey of pain, since only through that experience one comes to discover the true meaning of God's grace. In St. Paul's words: "my power is manifest in weakness" (Cor. 12,9). In Jungian terminology, it is always the mark of higher ego integrity. Humility could lead to timid, unassertive, and prone to shame and embarrassment behaviours like in situations of personal failures and is characterized by negative self-evaluation and hiding from other's evaluations. All these are examples of the dark side of humility. In contrast, humility could coexist with confidence, like in case of hard work and personal success with associated feelings of authentic pride, guilt and prestige.

Author contributions: The author accepts responsibility for the entire content of this submitted manuscript.

Research funding: None declared.

Competing interests: The author states no potential conflict of interest.

Informed consent and ethical approval: The conducted research is not related to human use. 


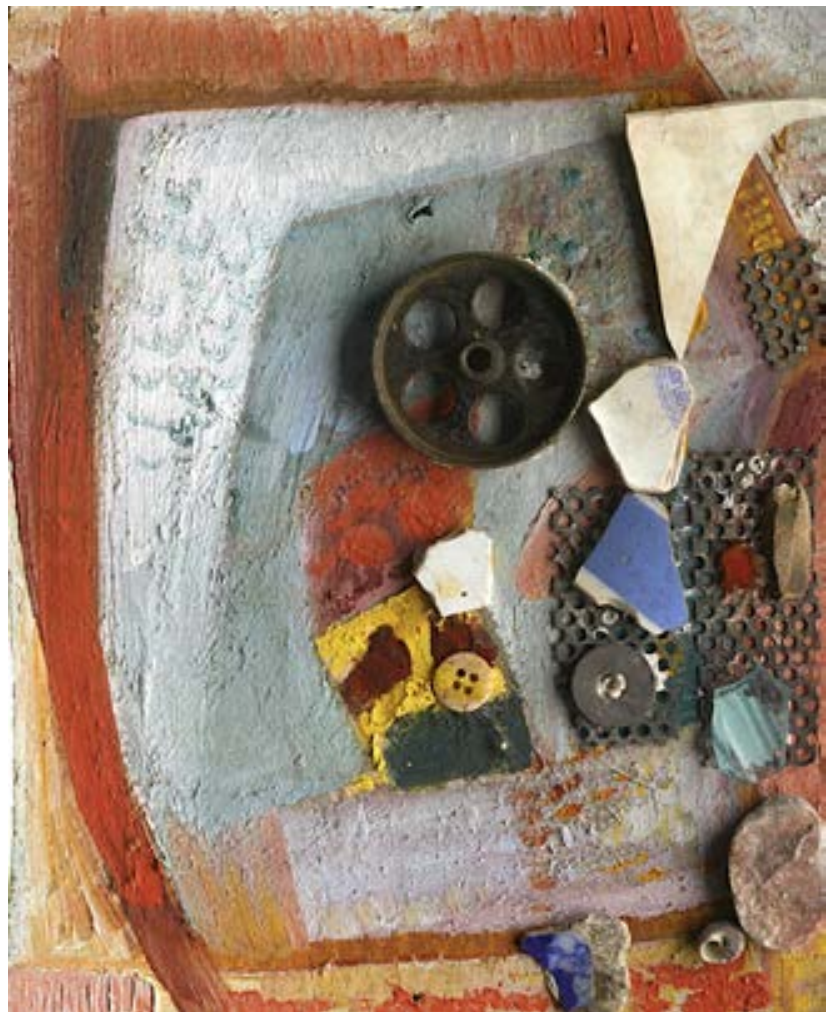

Fig. 1: Kurt Schwitters: Merz Picture with Porcelain Fragments, 1945-47, private collection (https://commons.wikimedia.org/wiki/File:Merz_Picture_with_ Porcelain_Fragments.jpg)

\section{Literature}

Asaad T (2015) Sleep in ancient Egypt. In: Chokroverty S, Billiard M (Eds.) Sleep Medicine. New York: Springer.

Blerk van NJ (2018) The emergence of law in ancient Egypt: the role of Maat. Fundamina 24:69-88.

Guggenbuhl-Craig A (1971) Power in the helping professions.

Woodstock CT: Spring Publications Inc.
Edinger EF (1985) Anatomy of the psyche: alchemical symbolism in psychotherapy. Peru IL: Open Court Publishing Company.

Hayes JA (2002) Playing with fire: countertransference and clinical epistemology. Journal of Contemporary Psychotherapy 32: 93-100.

Jones A (Ed.) (2000). The Jerusalem Bible. New York: Doubleday, Random House Inc.

Jung CG (1963/1989). Memories, dreams, and reflections. New York: Random House Inc.

Jung CG (1968) The archetypes and the collective unconscious. CW 9, Part I. Princeton NJ: Princeton University Press.

Jung CG (1969) The practice of psychotherapy. CW 16. Princeton NJ: Princeton University Press.

Kalsched D (1996). The inner world of trauma: archetypal defenses of the personal spirit. New York: Routledge.

Kalsched D (2015) Trauma and the soul: a psycho-spiritual approach to human development and its interruption. New York: Routledge.

Russell J (1981) The meanings of modern art. London: Thames \& Hudson.

Samuels A, Shorter B, Plaut F (1986) A critical dictionary of Jungian analysis. New York: Routledge \& Kegan Paul.

St. Augustine (2007) The confessions of St Augustine: Books 1-IX (Selections). Mundelein IL: Bolchazy-Carducci Publishers Inc.

\section{Author's biography}

\section{Jadranka Milovanovic}

Practicing Jungian Psychotherapist in Baltimore City on the East Coast of USA. Prior to war in her native Yugoslavia, she was a nurse. War forced her to move to the Mediterranean island of Malta where she practiced nursing and studied psychology. She worked with refugees both in Malta and in the USA. This experience continues to stimulate her ongoing interest in healing from extreme adversity, including involuntary dislocation from one's home. In life she draws strength from her Catholic faith, Jungian orientation to life, and by staying connected to her European roots. 